\title{
The Will to Political Power: Rwandan Women in Leadership
}

\author{
M. Juliana Kantengwa, MP*
}

... societies that recognise the real and untapped socioeconomic, cultural and political power of women thrive. Those that refuse to value and leverage women's talent, energies and unique perspectives remain developmental misfits.

Abstract Ruanda has one of the highest representations of women in parliament in the world. This article examines, from the perspective of a female MP in parliament, the dynamics behind the process of supporting more women assuming leadership positions in parliament. The article argues that the implementation of an electoral gender quota certainly carves the space necessary to allow more women to enter politics, nevertheless, a constellation of factors is needed to work together in order to create the enabling environment necessary for the quota to be effective. Some of these factors include (but are not restricted to) challenging the hierarchical gender relations in post-genocide Rwanda; the political will on the part of the government to engender politics; the role of national machineries in monitoring and pressing for gender-sensitive national policies, as well as the strategic mobilisation of female parliamentarians backed by the progressive new Rwandan constitution.

\section{Introduction}

The use of electoral gender quotas accelerated greater representation of women in the Rwandan parliament, who claimed 48.8 per cent of parliamentary seats, the highest in the world, ${ }^{2}$ after our first ever multiparty elections in 2003 This article will argue that while the use of electoral gender quotas is a useful and important mechanism, a multiplicity of factors came into play in a synergistic manner to produce the Rwandan scenario. Some of these factors included the 'paradigm shift', which was the outcome of the changing socioeconomic roles of women after the genocide; the political will to engender Rwandan politics and society; the use of national machineries to promote the status of women; the strategic mobilisation of female parliamentarians; the legal and institutional mechanisms that were embedded, backed by the progressive new Rwandan constitution, as well as the role of some non-state actors.

\section{Rwanda's historical perspective}

Rwanda existed as a nation State several centuries before colonisation of the African continent, as a stable, strong central African Kingdom, with an appreciable level of civilisation. The State of Rwanda today is not a colonial creation or an amalgamation but was carved out of this Kingdom. From the advent of colonialism, through to post-independence, Rwanda (1899-1962) and up to the 1994 genocide, divisions based on ethnicity, region, religious and gender discrimination characterised Rwanda's political governance.

Post-colonial politics led to mass killings in 1959, which led to a large part of the population fleeing to neighbouring countries, creating some of the earliest refugee populations on the African continent. Over the same period, policies of exclusion were visible in daily decisions and actions in education, employment, freedom of expression and movement, and finally culminated in the 1994 genocide.

In a period of only 100 days, close to over one million people, mainly Tutsis, and some moderate Hutus, perished at the hands of an extremist genocide-intent regime. Men, women 
and children were killed simply because they belonged to a socially constructed classification of ethnicity or simply because they did not support the genocide project.

During the genocide, women suffered the most horrible and dehumanising acts. Along with men and children, women were targeted and killed, often after witnessing the brutal killings of their family members (husbands, children, sisters, brothers, parents, friends and other relatives). Rape was used as a weapon of destruction and means of spreading HIV/AIDS to defenceless victims.

Like many other African societies, Rwanda is characterised by a patriarchal social structure that underlies the unequal socioeconomic and power relations between men and women. Traditionally, women had no known property rights and a woman's social status was bestowed by the husband's or son's status, except for a few exceptional cases in history.

The colonial leadership worsened the existing gender inequalities with the introduction of the formal education system. Women were not allowed into the formal education system until 40 years after their male counterparts; even then, they went to school to learn how to become good housewives for the new Rwandan elite - the colonial administration assistants. A gender disparity in educational opportunities was therefore established, and is still a reality today.

The 1994 genocide also resulted in unprecedented distortions in social relations within Rwandan society and again, women became the main victims. Poverty levels were aggravated with more than 68 per cent of women living below the poverty line, the majority of whom had no formal education. The illiteracy rate was well over 52 per cent, which implied limited or no access to employment.

According to the 2002 Population Census, women constituted 52.3 per cent of the population and 32.1 per cent of households were headed by women. In the more recent 2006 Household Survey, 56.9 per cent of the population lived below the poverty line, and 58.4 per cent of them were women, who also constitute the bulk of labour in subsistence agriculture, the mainstay of the national economy.
In July 1994, the fighters of the Rwanda Patriotic Front (RPF) halted the genocide, overthrew the genocidal regime and a Transitional Government of National Unity made up of eight political parties was put in place, in accordance with the provisions of the negotiated 1993 Arusha Peace Accords. Its core values included power-sharing, equity and equality of opportunity for all citizens, irrespective of gender, ethnicity, religion and region.

\section{The paradigm shift in gender roles in post- genocide Rwanda}

The transition government period (July 1994-May 2003) embarked on an ambitious reconstruction programme, the success of which largely depended on the involvement of everyone.

Women were called upon in the demanding tasks of physical and social reconstruction of the nation, repatriation and reintegration of refugees, social healing and reconciliation programmes. Further, women were also called upon to feed more than the 120,000 inmates accused of the crime of genocide; women became involved in peace building and pacification of the northern region of the country during insurgence and in justice and governance programmes. In all this, the Rwandan women responded with unparalleled resolve and proved themselves as formidable partners in all aspects of the recovery processes of the nation.

Today, Rwanda is no longer a shuttered but a hopeful nation. It is a nation that has come to terms with its tragic past with its new resolve of 'NEVER AGAIN'. The challenges of national reconstruction therefore, provided good process opportunities for the Rwandan women to demonstrate their abilities and to free their own potentials. Women in Rwanda account for 52.3 per cent of the total ${ }^{3}$ population and they have earned national recognition as a force to be reckoned with when contemplating national policies and programmes.

The challenges of national reconstruction also provided equally good educative opportunities to Rwandan society, to gradually let go of the traditionally cherished prejudices and stereotypes. The change in the perceptions of the social constructs of gender was evident; gender roles were changing and the Rwandan society was undergoing a paradigm shift. 


\section{Political imperatives and commitment to women's empowerment}

A notable characteristic of the post-genocide Rwandan leadership has been the strong commitment and political will, right from the very highest level, to promote gender equality and women's empowerment. The issue of gender equality was aggressively integrated in peace building initiatives in the post-conflict society. The rights of women and girls were recognised and acknowledged in national development, in education and health programmes, in property ownership and in all other spheres of life, while the fight against gender-based violence and particularly violence against women, took centre stage as an issue of national concern.

The evolution of the current strong political will/commitment to promote women as a pillar of good governance within the State of Rwanda can be traced way back into the last two decades or so, within the RPF's political ideology of equal opportunity for all Rwandans and whose core values of power sharing, equity and equality of opportunity greatly influenced and informed the negotiations of the Arusha Peace Accords.

Rwandan women joined the RPF struggle perceiving it as an organisation in which everyone found a voice and recognition. During the July 1994-May 2003 transitional government, RPF women party members were posted to many decision-making positions within the RPF's share of political appointments in the ruling transitional government.

In 1994, a total of 70 seats in parliament were shared among the eight political parties in accordance with Arusha Peace Accords of $1993^{4}$ and women then occupied 16 of the seats; equal to 23 per cent. However, RPF as a constituent political party within the ruling transitional government had a total of 46 per cent of its parliamentary seats occupied by women; which was six out of the total share of 13 seats in the transitional parliament. For people in Rwanda, the current percentage of Rwandese women in parliament of 48.8 per cent was not altogether unexpected when RPF won as the majority party after the 2003 parliamentary elections. Rwanda's current ruling political party, the Rwanda

Patriotic Front-Inkotanyi (RPFI) has its roots in a liberation movement/struggle born in exile by Rwandans in the diaspora who had been denied a homeland for almost 40 years by successive despotic regimes that ruled Rwanda until the 1994 genocide. The unifying factor for the then Rwandan diaspora was the desire for social justice, economic and political rights but above all, a sense of belonging and national identity.

\section{5 'National machineries' in the promotion of the status of women}

Since the ruling transitional government of National Unity was a ruling coalition, it was necessary to elaborate a common agenda or an orientation along which the country would be navigated up to the end of the transition.

It is against this background that the resolutions from the National Inter-Party consultations of 1999 resulted in a consensus document on the 'Minimum Shared Program', ${ }^{5}$ which among other things, provided direction and defined the national development objectives for the next 20 years, as articulated in the national 'Vision 2020'.

High on the agenda was the need to accelerate women to ascend into decision-making apparatus of the State, by putting in place instruments and mechanisms to dismantle the legal discrimination and marginalisation that had characterised their past. The use of 'national machineries' was adopted as set out by the Beijing Platform of Action as an institutional mechanism for the advancement of women. This included the Ministry of Gender as a fully fledged Ministry responsible for gender and women empowerment and was headed by a woman with a strengthened mandate of gender mainstreaming in all ministries and programmes of the State.

National Women Councils were established from the grassroots to the national level and were mandated to mobilise and educate women on the need to participate in politics as a necessity for improved social, economic and political conditions of their families and the entire country.

A national gender policy was elaborated as the mainstream national policy and a gender approach to development was institutionalised. Affirmative action for women was adopted as an interim measure to offset gender gaps emanating from cultural and historical disadvantages. 
The Ministry of Gender and Women in Development, with a clear and focused mission of promoting gender equality and equity, was mandated to facilitate the mainstreaming of gender concerns throughout the national development processes. At the 4th World Women Conference in Beijing, the Rwandese delegation had no positive story to tell, except of their suffering. However, the delegation came back determined to implement the Beijing Platform of Action with its 12 critical areas of concern.

The Ministry played an eminent catalytic role in the reinforcement and creation of national mechanisms for women's promotion and in the subsequent promotion of the positive image of the Rwandese woman as a good resources manager and peacemaker, as described below.

\subsection{Promotion of gender equality}

Through the medium of the Women's Councils established in 1999, women were mobilised to participate fully in areas of decision-making. This was carried out through training, sensitisation seminars and information campaigns targeting women, local leaders, policymakers, administration staff, gender focal points, NGO staff, women's associations, teachers, religious leaders and other opinion leaders and community shapers throughout the country, on the basic human rights of women. All this would not have been possible without the generous funding from international partners.

\subsection{Promotion of women's economic empowerment}

The majority of Rwandan people, and particularly the women, are very poor. After the genocide, women lacked the basic needs of shelter, food and clothing. The ministry became involved in a programme to combat the feminisation of poverty, by supporting women in building their own houses, joining microfinance projects and education and training programmes, to equip them with the essential skills required in national development. A guarantee fund was established to facilitate women's access to credit and involvement in income-generating activities.

\subsection{Accelerated acquisition of legal rights for women}

The accelerated acquisition of legal rights for women was ushered in by the law on Matrimonial Regimes, Liberalities and Successions (November 1999). ${ }^{6}$ (Matrimonial regime is a body of rules fixed by this law governing agreement between spouses on the management of their property.)

This piece of legislation enabled Rwandese women, for the first time and as individual citizens, to acquire personal rights, property rights, and the right to inherit and succeed property from their parents and spouses.

The coming into force of this law served to revolutionise mentality and attitudes and elevated the social status of women in Rwanda. Gender approach became accepted as the way forward. Gender dimensions were integrated into the land policy and law, in the decentralisation policy and law, and in agriculture policies and programmes, so that men and women have equal access to and control over land and other agricultural inputs. All previous legal provisions that discriminated against women were reviewed or even abrogated, while legal vacuums were researched and filled. Women now have full property rights including land rights.

\subsection{Adoption of the National Gender Policy}

The National Gender Policy was developed by the Ministry of Gender, from extensive consultations with various stakeholders including government departments, private sector, civil society organisations and other focused groups of the population. The Policy is a road map on how gender dimensions are incorporated in daily decisions of national life such that the needs of men and women, boys and girls are integrated in national policies, programmes and priorities.

This serves to ensure that there is equal access to and control over economic opportunities, political participation, social services and emerging opportunities, such as information and communications technology.

\subsection{The National Decentralisation Policy}

This Policy favours the integration of women in decision-making by the representation of women at the various local government administrative levels. Departments in charge of gender issues have been set up at provincial and district levels and women representatives are automatic members of the consultative committees at sector and cellule levels. The State of Rwanda is organised into four provinces and the City of Kigali, 30 districts, that are further subdivided into sectors, cellules and villages, the latter being the smallest administrative unit. 


\section{The power of organising around a common good}

Our view is that a lot of lip service is still being paid to the concept of Africa's ownership of its development agenda. This must change: it must be accepted that only Africa can develop itself, that aid is only a catalyst, and even more importantly, that effective aid is that which fits national priorities. $^{8}$

Rwandan women organised themselves around programmes and activities that promoted their common good and solicited for the support of men as their development allies. After the 1994 genocide, the Rwandan population was in total disarray. The women ministry was instrumental, calling on women to organise themselves in order to solve the multitude of problems and challenges that threatened their very livelihoods in a multifaceted manner. The call was heeded and the result today is as follows:

- Women Councils with elected committees from village level up to national level, with an active national secretariat that creates a follow-up on the Beijing plan of action. These Councils are mandated with identifying areas of concern that impede the advancement of women and packaging these concerns for dissemination in all forums at all levels and from all corners of the Rwandan territory. The pressure they generate is usually reflected in district plans of action and in parliamentary debates.

- The Youth Council, like the women councils, has elected representation from village level to national levels. These serve to mobilise young Rwandans to learn to play a role as participants in national development.

- Women Associations that existed before the genocide were few and organisationally weak. These Associations have been revitalised, strengthened and reinforced and many new ones mushroomed under the umbrella organisation Pro-Femmes Twese Hamwe. The number of registered Associations has continued to grow from 13 in 1994 to well over 43 today. Many more are not yet registered. The different associations are comprised of women from varying socioeconomic backgrounds with the aim of making a difference in the lives of the women and their communities. They have a common agenda which includes peace building, national unity and development.

- In 1999, Pro-Femmes Twese Hamwe won a UNESCO award for Peace and Tolerance.

This collective as it is popularly known, together with other women networks, sustained an ever-mounting pressure on the government of the day on the need to recognise women as equal partners in national development.

- Unity Club was born in 1995, as a forum for the spouses of ministers and women ministers, past and present, with a mission to promote and forge unity and reconciliation among our top leadership and to advocate for the wellbeing of vulnerable children, especially those living in orphanages. They constitute a form of cross-party coalition lobby in that they promote understanding among top level politicians from different political walks of life.

- Rwanda Women Leaders Caucus was founded in 2002 by women in different leadership positions, with a mission to bring together and promote a critical mass of women leaders through training, organising and advocacy. It brings together women leaders from grassroots to national levels. At the Caucus, women learn the art of public speaking, network with renowned women activists, establish networks and 'girls' clubs' and learn how to 'dream big'.

Women's organisations and networks, including the collective Pro-Femmes Twese Hamwe, the Rwanda Women Leaders Caucus, the Forum for Rwanda Women Parliamentarians (FFRP), The National Council of Women, as well as the Ministry of Gender and Women Promotion together, and in a concerted effort, achieved the following:

- Reviewed and lobbied for the repeal of all laws that subscribed to inequalities or any other forms of discrimination against women such as issues of nationality, property ownership, family relations, etc.

- Mainstreaming gender approach in all national planning and development.

- Ensuring that the budgeting system in the country is engendered at all levels of national expenditure.

- Sensitising the population at large and women in particular to the existing inequalities 
between men and women, boys and girls and on the right to education, access to and right to inherit property including land.

- Educating leaders and planners, both men and women on gender issues, concepts, tools, etc.

- The national gender policy as the road map to achieving equity in Rwandan society.

- Mobilised women to give their views during the constitution drafting process; to turn up in big numbers for the voting processes as well as run for political office.

- Building networks with men especially among the commission who were drafting the constitution and within parliament, men who will debate the final draft and using gendersensitive men to reach out to fellow men.

7 The strategic niche of female parliamentarians and the process of engendering the constitution The Forum for Rwanda Women

Parliamentarians (FFRP) is a forum for women legislators from different political parties. Founded in 1996, the forum has registered several achievements as a cross-party coalition. Notable among them is the ability to sustain themselves as a united front for the feminine agenda against various party pressures, all through the transitional period up to the present day. Together, they established a gender desk whose purpose is to assist the women parliamentarians to scrutinise and ensure that all draft bills including the annual state budgets, are engendered before adoption by parliament.

It is this forum that played a historical and pivotal role in engendering the new Rwandan constitution. The forum members benefited from the experiential learning gained through visits to the parliaments of South Africa, Norway and Sweden.

A multidisciplinary committee was formed from across the various institutions and women groups carried out nationwide training, awareness building and sensitisation on the constitution. Grassroots consultative processes resulted in a women's memorandum to the Constitutional Commission that voiced the wishes and aspirations of the Rwandan women.

The mobilisation was so successful that they were able to overcome the earlier deficit in women seeking leadership positions within their communities. While the legal provisions in the local government Act provided for women quotas of at least 30 per cent of seats, grassroots and local government elections of 1999 and 2001 respectively, demonstrated that women were not yet well primed to compete for public office. It was not uncommon to find that candidates to fill the seats reserved for women were hard to come by. Evidently, quotas and political will alone were not enough. Women were not yet ready. Yet as a consequence of the mobilisation work that took place, over 240 women candidates competed for the 24 constitutionally reserved seats for women.

\section{Changes as ushered in by the new constitutional provisions}

The entire text of the new Rwandan constitution $^{9}$ is about equal opportunity and social justice and above all, the 203 articles are fully engendered and the guiding spirit is largely based on the Convention on the Elimination of all forms of Discrimination Against Women (CEDAW) convention and the Beijing Platform of Action.

Section 10 of the preamble reads as follows: 'committed to ensuring equal rights between Rwandans and between women and men without prejudice to the principles of gender equality and complementality in national development'.

Article 9 of the same constitution spells out the six fundamental principles of the constitution, which are in essence the pillars of the Rwandan constitution.

The provision stipulates that: 'The Rwandan state undertakes to conform to the following principles and to uphold them: ...' and Section 4 reads: 'Building a state governed by the rule of law, a pluralistic democratic government, equality of all Rwandans, and between women and men reflected by ensuring that women are granted at least thirty percent of posts in all decision making organs'.

Some 22 Articles of the constitution are explicit on gender equality and complementality in their provisions and these are articles: 7, 8, 9, 11, 16, 23, 26, 27, 28, 29, 37, 40, 51, 52, 54, 76, 77, 82, 126, 185, 187 and 201.

Articles 54 and 76 of the constitution specifically enshrine the Beijing declaration to allow for quotas and women reserved seats: 


\begin{tabular}{lll}
\hline \multicolumn{2}{l}{ Table 1 Situation before and after the new constitution } \\
\hline Institution & Before constitution (\%) & After constitution (\%) \\
\hline Legislature & 25 & 48.8 \\
Senate & N/A & 34.6 \\
Executive & 13.7 & 37.9 \\
Supreme Court & 3 & 42.9 \\
Local Government & 3 & 41.6 \\
\hline
\end{tabular}

Article 54: 'The political organizations must constantly reflect unity of the people of Rwanda and, gender equality and complementality, of men and women, whether in the recruitment of members, putting in place organs of leadership and in their operations and activities'.

Article 76: 'The Chamber of Deputies is composed of eighty (80) members, as follows:

Fifty three (53) are elected in accordance with the provision of Article 77 of this constitution; Article 77 is about proportional representation in electing the 53 seats. Twenty four (24) women reserved seats'...

Article 82 refers to the Senate composition and it is explicit with the clause ... 'at least $30 \%$ women'. The electoral laws borrowed heavily from the corresponding section of the constitution. Thus the different political party lists had to have at least 30 per cent minimum of women candidates.

Articles 185 and 187 establish the Gender Monitoring office and the National Council of women, both of which are institutional mechanisms to safeguard and sustain the continued promotion of women as well as a gender approach in national planning and evaluation.

Article 10, Section 6 refers to a democracy through consensus. This culture of seeking for a consensus as opposed to confrontational politics is helping Rwanda rediscover herself among nations and her people especially the women, to aim for even greater heights.

In 2003, a woman dared stand for presidential elections; she only pulled out at the last hour in some coalition building, but had scored the point by getting on the stage and sensitising the minds of the electorate that women too can be heads of States.

In effect, the Rwandan constitution is a legal instrument that explicitly enshrines the equality of Rwandese men and women in the affairs of national development.

Table 1 demonstrates the actual situation before and after the enforcement of the new constitution.

Under-representation of women before the enforcement of the new constitution as indicated in Table 1 was also apparent among trade unions, cooperatives, and professional organisations as well as grassroots organisations. However, with the new constitutional dispensations, the situation improved greatly, especially in Rwanda's parliament.

Women head a number of State Corporations, e.g. the 1st Vice Governor of the central Bank, the Auditor General, the Deputy Ombudsman, Deputy Commissioner of Police, the Commissioner of Rwanda Revenue Authority, the Director General of the national insurance cooperation (SONARWA), the Director General of the national office for tourism and national parks (ORTPN), to mention but a few examples, are all women.

Of the Special Commissions provided for in the Constitution, only three out of five are headed by women, i.e. the National Human Rights Commission and the National Unity and Reconciliation Commissions and the Gender Observatory. It is worth noting that even the Head of the Gacaca Courts is a woman. (These are Traditional Community Courts mandated to speed up genocide cases.) The presence of women in high political office is being echoed in other sectors of the society such that women are 
increasingly becoming more visible and accepted in different arenas of decision-making power.

\section{Challenges faced by women during the electoral process}

Literacy levels are still low in rural Rwanda and the problem is more pronounced among women. Only 47 per cent are literate compared with 58.1 per cent literate men. Dealing with an illiterate electorate presents its own difficulties and it worsens when women are involved. The more literate men tend to lead women's opinion such that a woman will be inclined to vote for the husband's choice. To counter this, women were educated on the benefits of the secret ballot and were assured that nobody would get to know their choice.

There was also the issue of elite women who wanted to exclusively highjack the 24 womenreserved seats. Rural women were outwitted as the male electorate almost invariably voted in favour of the urban elite women; thereby distorting the principle of equal opportunity. This was, however, counteracted through the use of women's grassroots organisations that were mobilised to vote for the women they were sure would most serve their interests.

Moreover, male colleagues were usually better connected with wider networks among the local administration and local communities, than women. The whole campaign business and terrain seemed to favour the more male behaviour, e.g. staying overnight outside the home environment after the political campaigns and rallies. Men found it much easier than women to relate to the electorate in social evenings. At rallies, male colleagues were quite often perceived and judged to be 'better' candidates by the electorate; women candidates were not a familiar phenomenon. It is true that men and society are gradually accepting women in the public domain but traditional residual thinking can still be detected. At some rallies, campaign tools such as voice amplifiers may be in short supply and in such cases, women's voices are clearly at a disadvantage.

Proportional representation is a good mechanism for women regarding practical field challenges, in that the rules are already set and the lists are not changeable such that candidates do not compete when drawn on the same list.
10 Reflections from the Rwandan scenario and the way forward

Rwanda went through a transition period of nine years, from extreme violence to a stable secure environment with the rule of law. The net effect on the Rwandans was that they became very responsive to changes in mindsets. Timing seems to be important in post-conflict countries, as this is an opportune moment to take full advantage of this receptive period and introduce changes, especially during transitions and the process of drafting of new constitutions. It is also the right time to enshrine the ratified international legal instruments and to include legal safeguards that promote/enhance women's participation. The electoral laws must contain clear safeguards to promote and protect women's participation before jumping on the campaign wagon.

Building coalitions and solidarity among women's groups was critical for transforming society and catalysing opportunities for women's political participation. From the outset, the women of Rwanda realised that they lose out the most, along with their children, in conflict situations and this became a binding force among women and across party and ethnic lines. Peace and security were campaign issues women voted for in the last elections. For Rwandan women, this was not the time to pull each other down but to form human ladders and support each other to climb.

There is need for strong political will/commitment at the top to lead the way or at least open the way. Gender equality and equity is about social justice and needs to permeate political party ideology. Further, drawing an all inclusive national gender policy as a crosscutting development parameter with a clear action plan to institutionalise gender approaches to planning, programming and budgeting is an important milestone. This also includes doing away with laws that are gender discriminatory. Moreover, strong State partnership with civil society and private sector facilitates policy implementation and speeds up national development in addition to facilitating in the generation of the critical mass of conscious women to sustain the momentum. Consolidating and strengthening gender machineries, like the Ministry of Gender, Women Councils, women's organisations, women's leagues, caucuses, etc. is useful in order to refine and sustain the momentum. 
Involvement of men from the outset through particular campaigns directed at them, as well as efforts to build partnerships with the men who lead opinions, both had positive impacts on the developments that unfolded in Rwanda. For example, the Rwanda women leaders' caucus was created as a permanent network for sharing leadership and experiences built on partnership of men and women. In addition, building partnerships with actors in the African region and beyond was also highly instrumental, e.g. international partnerships and outreach were

\section{Notes}

* This article is a synthesis of a presentation given at a seminar (19-20 June 2007) at the Nucleus of Interdisciplinary Women's Studies of the Federal University of Bahia, Brazil (Costa (ed.) 2009, House of Representatives. Trails of the Power of Women: International Experience in Affirmative Action, Brasilia: Edicções Board: 143-63).

1 President Paul Kagame addressing the International Conference on 'Gender, Nation Building and the Role of Parliaments', Kigali, 22 February 2007.

2 Inter-Parliamentary Union Press Release, May 2004.

3 General Population and Housing Census Report, Kigali, Rwanda, 31 August 2002. critical in providing technical, financial and rolemodelling support. There was in fact a CEDAW expert within the FFRP.

In conclusion, the use of electoral gender quotas is a workable tool to increase participation of women in high political office, but the women need to use this opportunity of affirmative action while it lasts, to mobilise themselves into a critical mass that is capable of sustaining the momentum and capable of permeating societies well beyond the use of tools of affirmative action.

4 Arusha Peace Agreement between RPF and the Government of Rwanda, Arusha, Tanzania, 1993.

5 Raporo z'Ibiganiro Village Urugwiro, 1998-1999, Kigali, Rwanda.

6 Law No 22/99 of 12/11/199 to supplement Book 1 of the Rwandan Civil Code and to institute part five Regarding Matrimonial Regimes, Liberalities and Successions. Kigali, Rwanda.

7 National Gender Policy, Kigali, December 2003.

8 Paul Kagame, Development Partners meeting, Kigali, 6 November 2002.

9 The Constitution of the Republic of Rwanda, 4 June 2003. 